\title{
Magda zupanăǐ USPOSOBLJENOST IN POTREBE TRGA DELA PRIHODNOSTI - ODGOVORNOST SEDANJOSTI
}

\section{POVZETEK}

Gospodarstva Evrope vedno glasneje opozarjajo na nevarno razhajanje $v$ usposobljenosti in znanjih, ki ustrezajo potrebam delodajalcem, ter obstoječo ponudbo, kar znatno vpliva na (ne)- konkurenčnost nacionalnih gospodarstev. Znanje, usposobljenost in kompetence v družbi znanja namreč postajajo nujni pogoj konkurenčnosti (globalnih) trgov dela, kar je v kriznih časih še pomembnejši dejavnik za obstoj gospodarskih subjektov na trgu. Z drugimi besedami, za družbo znanja kot cilj integrirane Evrope je pri oblikovanju celostnih politik velikega pomena identificiranje sedanjih in prihodnjih potreb po usposobljenosti ter sodobnih znanjih. Šele celostno in sistematično spremljanje in identificiranje potreb namreč omogočata uravnoteženje ponudbe in povpraševanja na trgih dela, s tem pa tudi večjo konkurenčnost in visoko stopnjo socialne kohezije. Ustrezno usposobljena delovna sila vseh kvalifikacij in vseh generacij, vključena v vseživljenjsko izobraževanje, se namreč hitreje in uspešnejše prilagaja zahtevam sodobnega dinamičnega gospodarskega okolja in (poklicne, sektorske in geografske) mobilnosti.

Ključne besede: usposobljenost in znanje, znanje, trg dela, konkurenčnost, vseživljenjsko učenje

$\mathrm{V}$

nepredvidljivem tržnem gospodarstvu seveda ne moremo predvideti vseh potreb trgov dela, vendar lahko na podlagi sektorskih premikov in različnih scenarijev sklepamo na možno povečanje oziroma zmanjšanje potreb po posameznih znanjih ter usposobljenostih, ki so znaten dejavnik uspeha nacionalnega gospodarstva, podjetništva in inovativnosti.

\section{EVROPSKA UNIJA IN UKREPI ZA VEČJO USPOSOBLJENOST NA TRGU DELA}

Usposobljenost in znanje v sodobnem svetu pomenita gonilo napredka in konkurenčnosti. Po zagonu t. i. lizbonske strategije v letu 2000 je Evropski svet marca 2005 sprejel sklepe o ponovnem začetku izvajanja omenjene strategije $\mathrm{z}$ osredotočenjem na rast in ustvarjanje novih delovnih mest, s poudarkom na »odzivanju na nove poklicne potrebe, ključne veščine in prihodnje zahteve po spretnostih z izboljšanjem opredelitve in preglednosti kvalifikacij, njihovega učinkovitega priznavanja ter potrjevanja neformalnega in priložnostnega učenja .

V decembru leta 2004 predloženo maastrichtsko sporočilo je znotraj t. i. koebenhavnskega procesa ponovno poudarilo pomen interakcije usposabljanja in izobraževanja z zahtevami trgov dela (ekonomija znanja) ter zahtevo po razvijanju preglednega evropskega kvalifikacijskega okvira. Pomen ustreznega razvoja usposobljenosti za družbo znanja kot posebni cilj opredeljuje tudi v letu 2002 sprejeti delovni program »Izobraževanje in usposabljanje $2010 \ll,{ }^{1}$ ki lizbonsko strategijo dopolnjuje 
z vidika izobraževanja in usposabljanja. Svet Evropske unije skupaj s predstavniki držav članic, ki so se novembra 2005 sestali v okviru Sveta ${ }^{2}$ ter razpravljali o vlogi razvoja spretnosti in veščin za doseganje ciljev lizbonske strategije, je Evropsko komisijo in CEDEFOP pozval, da izdelata pregled raznovrstnih sektorskih pristopov $\mathrm{k}$ pridobivanju veščin in sposobnosti za države članice, pristopnice in države kandidatke.

V okviru leta 2005 prenovljene lizbonske strategije in Smernic zaposlovanja za obdobje od 2008 do $2010^{3}$ kot ukrepov za doseganje ciljev strategije je za omenjeno tematiko pomembna predvsem Smernica številka 20, ki poudarja »izboljšanje usklajenosti s potrebami trga dela $\mathrm{s}$ pomočjo:

i) posodobitve in okrepitve institucij trga dela, zlasti zavodov za zaposlovanje, tudi z namenom zagotavljanja večje preglednosti možnosti za zaposlovanje in usposabljanje na nacionalni in evropski ravni,

ii) odpravljanja ovir za mobilnost delavcev po Evropi znotraj okvira pogodb,

iii) boljšega predvidevanja potreb po strokovni usposobljenosti ter »pomanjkanja in ozkih grl na trgu dela ter ustreznega upravljanja ekonomskih migracij«.

$\mathrm{V}$ podobnem kontekstu tudi Smernica številka 24 priporoča državam članicam prilagoditev sistemov izobraževanja in usposabljanja na način, ki ustreza zahtevam sodobnih kompetenc. $\mathrm{Na}$ nevarnost prepada med potrebami in ponudbo na trgih dela v Evropi je Evropska unija resno opomnila novembra 2007, in sicer v času predsedovanja Portugalske s sprejetjem resolucije Sveta za izobraževanje »Nova znanja in spretnosti za nova delovna mesta «, ${ }^{4} \mathrm{ki}$ je potrdila povezavo izobraževanja in usposabljanja v kontekstu vseživljenjskega učenja z zaposljivostjo in prilagodljivostjo posameznika na trgu dela. Resolucija izhaja predvsem iz zaključkov iniciative Skillnet kot orodja in mreže za zgodnje identificiranje potreb po usposobljenosti in zmanjševanje razhajanj, ki je bila ustanovljena v okviru CEDEFOP ${ }^{5}$ na željo držav članic Unije.

Slovenija je v času svojega predsedovanja v letu 2008 nadaljevala portugalsko iniciativo, tako da je na junijskem srečanju Sveta predložila zaključke Sveta »Predvidevanje in povezovanje potreb na trgu dela - iniciativa za delovna mesta in usposobljenost « ${ }^{6}$ Tudi spomladanski vrh 2008 v svojih zaključkih poudarja pomen vseh razpoložljivih instrumentov in orodij na ravni Unije za oceno prihodnjih zahtev glede usposobljenosti do leta 2020, predvsem v luči primanjkljaja v mnogih sektorjih ter upoštevaje vpliv tehnoloških sprememb, ekonomskih migracij in staranja prebivalstva kot tudi s tem povezanih prihodnjih korakov v predvidevanju potreb trgov dela.

\section{DOKUMENTI, KI SE NAVEZUJEJO NA PREDVIDEVANJE GLEDE DELOVNIH MEST}

Resolucija »Nova znanja in spretnosti za nova delovna mesta « države članice poziva k ukrepom, s katerimi bi prebivalce Evropske unije usposobile za potrebe sodobnih trgov dela ter s tem povečale participacijo na trgu dela, socialno vključenost, prilagodljivost in naložbe $\mathrm{v}$ človeški kapital, in sicer $\mathrm{z}$ i) dvigom ravni njihove usposobljenosti ter znanj oziroma prilagoditvami zahtevam sodobnega trga s preusmeritvami v perspektivne in boljše zaposlitve, ii) predvidevanjem potreb po strokovni usposobljenosti in vrzeli pri tem ter iii) uskladitvijo potreb gospodarstva z znanji, spretnostmi in ustrezno stopnjo usposobljenosti.

Resolucija konkretno države članice poziva, da usposobijo ljudi za nove zaposlitve v družbi znanja, prednostno tiste kategorije oseb, ki so najbolj izpostavljene ekonomski in socialni izključenosti. Dodatno je pobuda namenjena spodbujanju odličnosti pri usposabljanju na področju razvoja, raziskav in inovacij, podpori iskalcem zaposlitve $\mathrm{v}$ obliki svetovanja ter podpori informiranja o novih delovnih mestih. 
Resolucija dodatno poziva države članice $\mathrm{k}$ nadaljnjim ukrepom za priznavanje učnih re-

$V$ Ell se bo do leta 2020 odprlo do 100 milijonov delovnih mest. zultatov in k preglednosti priznavanja kvalifikacij v okviru evropskega okvira kvalifikacij. Pri tem daje tudi priporočilo o intenzivnejšem izkoriščanju sredstev strukturnih skladov pri doseganju zastavljenih ciljev.

\section{PRIHODNIE POTREBE PO USPOSOBLJENOSTI DO LETA 2020 - PREDVIDEVANIA CEDEFOP}

V letu 2008 je CEDEFOP v sodelovanju z mrežo Skillnet izdal prvo celovito publikacijo s pregledom predvidenih potreb po usposobljenosti do leta 2015, kasneje dopolnjeno za obdobje do leta 2020.

Predvidevanja vse do leta 2020 zagotovo ne morejo zagotavljati popolne zanesljivosti, lahko pa dajo podlago za oblikovanje nacionalnih politik na področju usposabljanja, izobraževanja in karierne orientacije. Splošni trend pred-

Slika št. 1: Predvidena raven zaposlenosti (za skupine poklicev) leta 2020 za EU-25

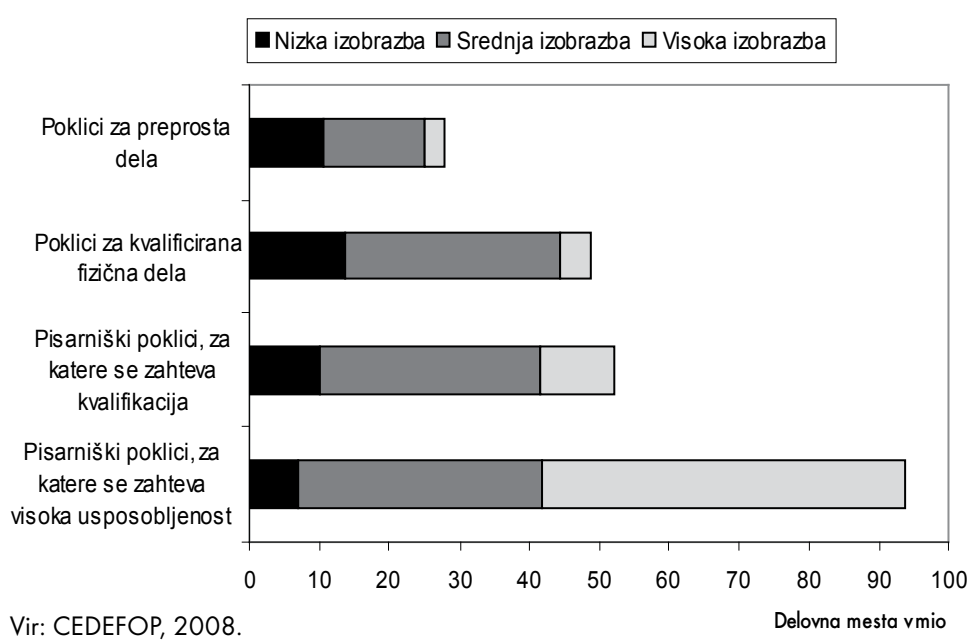

videvanj nakazuje rast števila delovnih mest; od leta 2006 do 2020 naj bi se tako v EU odprlo do 100 milijonov delovnih mest, ${ }^{7}$ od tega kar
80 milijonov t. i. nadomestnih ${ }^{8}$ delovnih mest. Omenjenemu trendu se morajo čim prej prilagoditi tudi sistemi izobraževanja in usposabljanja s ciljem absorbiranja vedno večjega nabora ključnih kompetenc. Predvidevanja slonijo na makroekonomskih projekcijah in napovedih sektorskih prerazdelitev, obsega proizvodnje in produktivnosti, zaradi finančne krize pa, kot že povedano, vključujejo določeno mero nepredvidljivosti in omejitve zanesljivosti.

Izsledki, objavljeni v publikaciji, dodatno nakazujejo trend vse večjih zahtev glede kvalifikacij za vse vrste poklicev (tudi za poklicne kvalifikacije poleg srednje in visoke usposobljenosti). Gre predvsem za zahtevo po vedno večji raznovrstnosti znanj (multi-skilling in t. i. mehka znanja) ter kompetenc. Obenem se bo z zviševanjem izobrazbe z razvojem družbe znanja zmanjševal delež poklicev z najnižjo izobrazbo (Slika št. 1). Zadnje čase je veliko pozornosti namenjene poklicem, ki se bodo pojavili ali se nadgradili vzporedno z novimi družbenimi spremembami in izzivi. Zaposlovanje na t. i. zelenih delovnih mestih kot posledica prehoda $\mathrm{v}$ nizkoogljično družbo in večanje deleža oseb, zaposlenih $\mathrm{v}$ osebnih storitvah ali storitvah nege zaradi staranja prebivalstva, pomenita potencialni nabor novih oblik zaposlovanja.

Ne glede na trenutno finančno krizo se bo delež storitev v skupni zaposlenosti še nadalje povečeval. Po predvidevanjih CEDEFOP bo do leta 2020 že tri četrtine zaposlitev v storitvah. Staranje prebivalstva Evrope (zmanjševanje razpoložljive delovne sile) se bo poleg

Trend sektorskih premikov zaposlenosti kaže upad zaposlitev v primarnem sektorju, počasno zmanjševanje oziroma stagnacijo v proizvodnem sektorju, že omenjena rast zaposlitev $\mathrm{v}$ storitvenem sektorju pa bo po predvidevanjih najbolj intenzivna $\mathrm{v}$ sektorju distribucije, poslovnih (svetovalnih) storitev ter v že omenjenih zdravstvenih in osebnih storitvah. 
Slika št. 2: Predvideno gibanje stopnje zaposlenosti v storitvenem sektoriu za EU-25 do 2015

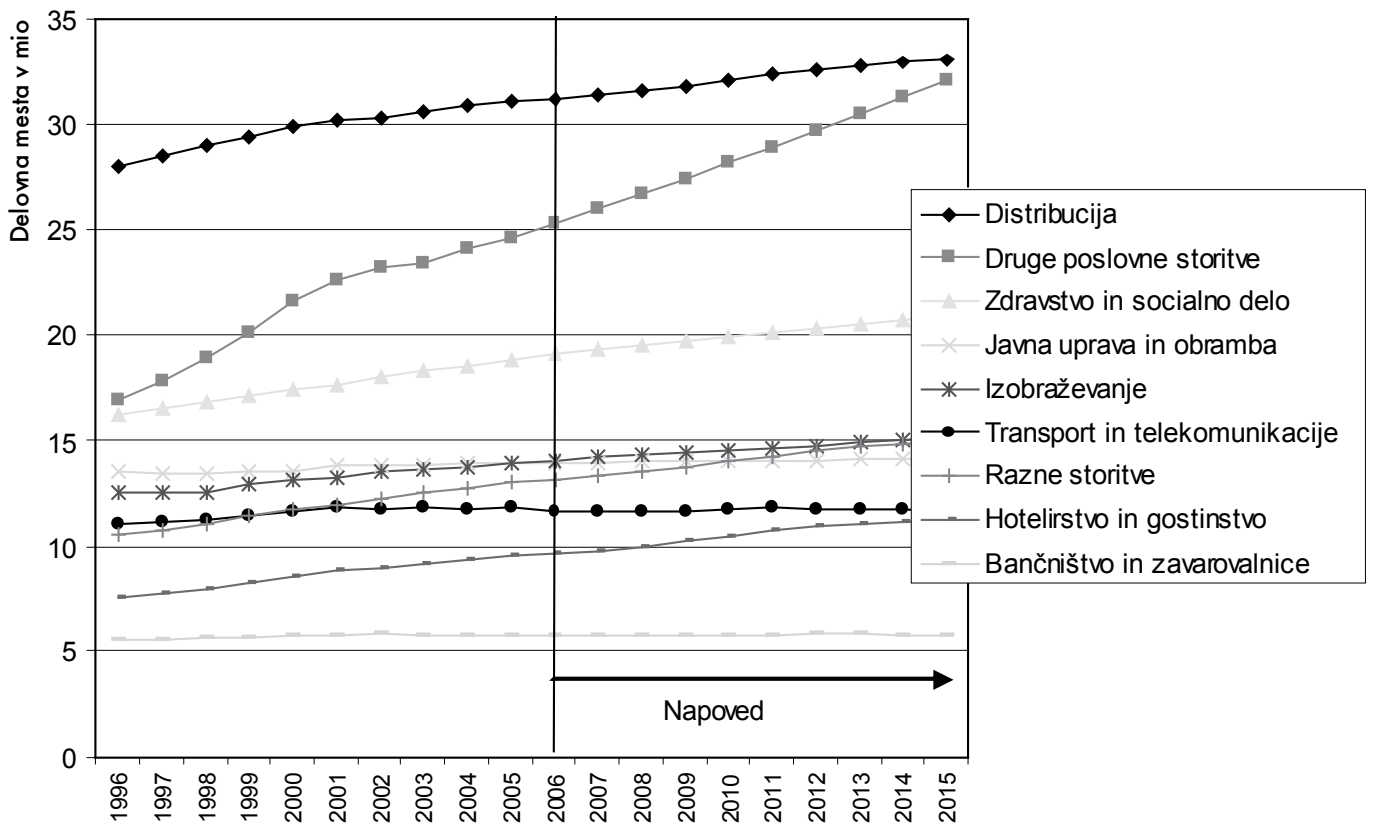

Vir: CEDEFOP, 2008.

obstoječe neustrezne kvalifikacijske strukture izrazilo kot pomanjkanje nadomestne delovne sile (tudi za preprostejša dela), ki je tudi morebitna migracija verjetno ne bo mogla zapolniti zaradi neskladja med ponudbo in povpraševanjem, saj znanja in usposobljenosti migrantov ne bodo ustrezni (Slika št. 2).

Razvoj potreb glede poklicnih ravni znotraj EU nakazuje, da v Evropi obstaja potreba po prilagajanju usposobljenosti s ciljem dolgoročne zaposljivosti. Število delovnih mest z najvišjo ravnjo izobrazbe naj bi se tako po napovedih CEDEFOP povečalo s 25,1 na 31,3 odstotka vseh delovnih mest, po drugi strani pa naj bi se delež delovnih mest $\mathrm{z}$ najnižjo izobrazbo zmanjšal s 26,2 na 18,5 odstotka (Slika št. 3). Iz opisnega sledi, da je v prihodnosti za zagotavljanje ravnotežja med ponudbo in povpraševanjem glede usposobljenosti in znanj na trgu dela pomembno predvidevanje potreb kot podlaga širokih in koordiniranih politik. To velja pred-
Slika št. 3: Pretekla in predvidena prihodnja struktura delovnih mest po ravni izobrazbe za EU-25

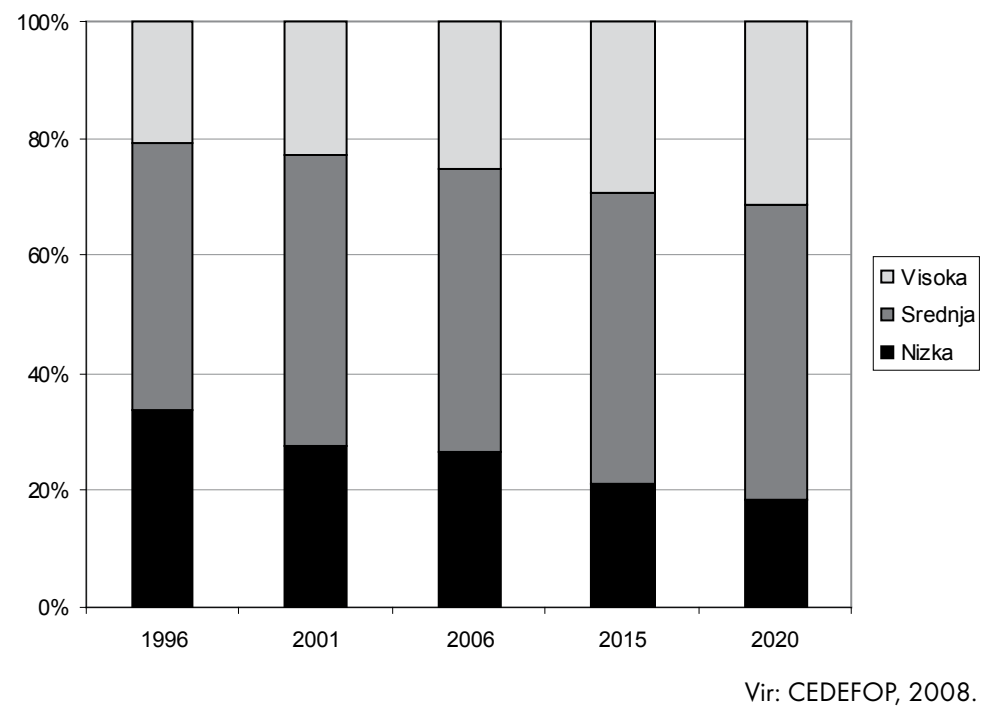

vsem $\mathrm{v}$ času krize in ob zahtevah po prestrukturiranju v produktivnejše sektorje in dejavnosti. 
Tabela št. 1: Delovno aktivno prebivalstvo po stopnji šolske izobrazbe v letu 2006

\begin{tabular}{|c|c|c|c|c|c|c|c|}
\hline \multirow{3}{*}{ Slovenija } & \multicolumn{7}{|c|}{2006} \\
\hline & $\begin{array}{l}\text { Dosežena } \\
\text { izobrazba - } \\
\text { SKUPAJ }^{9}\end{array}$ & Brez izobrazbe & $\begin{array}{l}\text { Nedokončana } \\
\text { osnovna }\end{array}$ & Osnovna & Srednja & Višja & Visoka ali več \\
\hline & 693.090 & 603 & 22.912 & 83.121 & 415.727 & 47.294 & 118.307 \\
\hline
\end{tabular}

Vir: SURS.

\section{PREDVIDEVANIA POTREB PO USPOSOBLJENOSTI ZA SLOVENIJO}

$\mathrm{Za}$ trg dela v Sloveniji je značilno, da še zmeraj prevladuje zaposlovanje $\mathrm{v}$ predelovalni industriji. Po podatkih SURS-a je bilo največ delovno aktivnega prebivalstva v prvem četrtletju leta 2009 zaposlenega $\mathrm{v}$ predelovalnih dejavnostih $(29,9$ odstotka), sedem odstotkov delovno aktivnega prebivalstva pa je bilo $\mathrm{v}$ istem obdobju zapo-

$\checkmark$ Sloveniji se dodatno izobražujejo visoko izobraženi in zaposleni ljudje, stariod 25 do 34 let. slenega $\mathrm{v}$ poklicih za preprosta dela. Zanimiv podatek za analizo neskladij med ponudbo in povpraševanjem je tudi dejstvo, da se skoraj dve tretjini v Slovenijo priseljenih oseb zaposli v dejavnosti gradbeništva. (Vir: SURS.)

Na podlagi podatkov SURS-a je prebivalec Slovenije, ki se dodatno izobražuje, v povprečju star od 25 do 34 let, visoko izobražen in zaposlen, ženske se izobražujejo v nekoliko večjem številu kot moški. Podatki za leto 2007 kažejo, da se je katerekoli oblike izobraževanja in usposabljanja udeležilo 50 odstotkov prebivalcev Slovenije v starosti 25-34 let, 45 odstotkov prebivalcev v starosti 35-49 let in zgolj 27 odstotkov oseb v starosti 50-64 let.

V Sloveniji je bilo največ (59,9 odstotka) delovno aktivnih prebivalcev konec leta 2006 srednješolsko izobraženih. Visokošolsko izobraženi (17 odstotkov) so bili številnejši kot tisti s končano osnovno šolo (12 odstotkov).
Več kot 40 odstotkov vseh odraslih se ni izobraževalo in si izobraževanja tudi ni želelo. Med udeleženci izobraževanja pa so prevladovali višje izobraženi odrasli, 39 odstotkov odraslih s srednješolsko izobrazbo in le 13 odstotkov oseb z dokončano ali nedokončano osnovnošolsko izobrazbo. Pomemben kazalec (ne)zavedanja o pomenu vlaganja $\mathrm{v}$ znanje in usposobljenost pa je podatek, da delodajalci redko dovolijo, da bi bile za izobraževanje porabljene delovne ure; več kot 80 odstotkov izobraževanja je namreč potekalo samo ali pretežno zunaj delovnega časa. Skrb vzbujajoče je tudi, da je ob nizki, nezadostni ali neustrezni izobrazbi/usposobljenosti interes za izobraževanje med brezposelnimi odraslimi znatno manjši kot med zaposlenimi - izobraževalo se je okrog 25 odstotkov vseh brezposelnih. Med osebami, vključenimi v programe za pridobitev izobrazbe, pa je bilo le 10 odstotkov brezposelnih (SURS, Teden vseživljenjskega učenja. Posebna objava, 8. 5. 2009). Trenutna finančna kriza in $\mathrm{z}$ njo povezana zahteva po prestrukturiranju, spremembe na ekonomskem in družbenem področju, hiter tehnološki razvoj ter pritiski staranja prebivalstva terjajo nov pristop v izobraževanju in usposabljanju, ki naj bi temeljil na konceptu vseživljenjskega učenja. Omenjena zahteva je pomembna za vse udeležence na trgu dela, za majhno gospodarstvo, kot je Slovenija, toliko bolj.

Vendarle, ali poznamo smer t. i. razvojnega preboja Slovenije? Kje se skriva potencialna konkurenčna prednost Slovenije oziroma kam naj se pri prestrukturiranju in nadgradnji delovne sile usmeri država? Prvi pogoj za ustrezna vlaganja 
Napovedi prihodnjih gibanj so nehvaležna naloga analitikov, vendar pa moramo v Sloveniji nedvomno razmisliti o naslednjih dejstvih:

- sedanja izobrazbena struktura je preslaba za prehod v družbo znanja;

- eksterni trg dela $\mathrm{v}$ obliki nezapolnjenih delovnih mest in interni trg dela $\mathrm{z}$ neskladjem med ponudbo in povpraševanjem nam nudita vpogled $v$ trenutno stanje ter pomanjkljivosti trga dela Slovenije;

- kljub nezanesljivosti trendov so razvidni trendi zatona posameznih dejavnosti, predvsem v sekundarnem sektorju;

- izobrazbeno strukturo sedanje delovne sile v Sloveniji večinoma poznamo (po podatkih IPTS $^{10}$ je približno 70 odstotkov delovne sile iz leta 2020 na trgu dela že zdaj).

v delovno silo je konsenz o razvojnih politikah in razvojnih poteh, podpirati je treba uspešne in perspektivne inovativne dejavnosti, ne zgolj vlagati v višanje stopnje izobrazbe ali usposobljenosti per se. $\mathrm{Z}$ drugimi besedami, brez kritične mase oseb, ki bodo ob visoki usposobljenosti inovativne in konkurenčne v svoji dejavnosti, nam še tako dobra prodajna ali marketinška strategija ne bo prinesla dodane vrednosti. Konkurenčnost Slovenije (kot tudi preostale Evrope, ki se srečuje s podobnimi izzivi na trgu delovne sile) dodatno še poslabšuje izredno hitra rast izjemno usposobljene in prilagodljive delovne sile tretjih držav (npr. države BRIC).

Šele ko bo dosežen konsenz o razvojni poti, lahko Slovenija razvije najpomembnejše, orodja za predvidevanje, se pravi ustrezno statistično »infrastrukturo«, in obveščanje o trendih, tudi kot vodilo za karierne usmeritve v smislu dolgoročnih zaposlitvenih možnosti.

\section{ZAKLJUČEK}

Krizni časi zahtevajo prestrukturiranje, kar pomeni prilagajanje obstoječe delovne sile novim znanjem in ustrezni usposobljenosti. Vendar se ob tem poraja več pomembnih vprašanj. Kateri so tisti sektorji, ki bodo Sloveniji prinesli več kakovostnih delovnih mest? Katere kvalifikacije bomo potrebovali in $\mathrm{v}$ katero smer se bo razvijalo naše gospodarstvo? Na katere trge se bomo širili, kakšna bo naša potencialna konkurenčnost glede na predvide- ne sektorske razvojne trende? In ne nazadnje, glede na staranje prebivalstva v Sloveniji, ali bomo imeli dovolj ustrezno usposobljene delovne sile, da bo nadomestila izpad odhajajočih generacij?

Brez premišljenih, med ključnimi vladnimi resorji in raziskovalnimi institucijami usklajenih ukrepov na trgu dela ter po po-

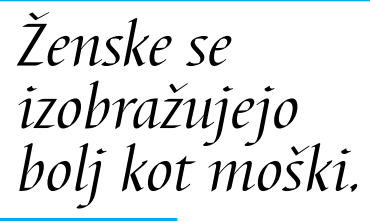
trebi revizij sistemov usposabljanja in izobraževanja bo prestrukturiranje v družbo znanja za Slovenijo težka naloga. Predvidevanje prihodnjih perspektivnih kvalifikacij oziroma potreb trga dela je temeljni pogoj tako za ustreznost in pravilnost izobraževalnih politik kot tudi za pravilno in perspektivno karierno pot posameznika. Šele ustrezni mehanizmi bodo omogočili resnično uvedbo in izvajanje politik prožne varnosti kot sodobne in prilagodljive poti $\mathrm{v}$ dolgoročno zaposljivost posameznika.

Evropski socialni sklad daje

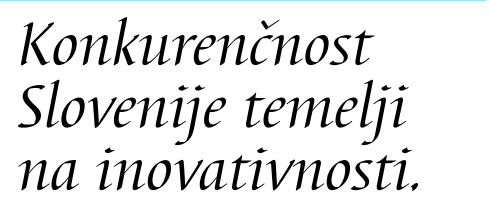

zeleno luč za črpanje svojih sredstev za podporo postavitve sistemov za spremljanje prihodnjih potreb na trgu dela. To ob kakovostno zastavljenem projektu lahko pokrije levji delež financiranja ter tako omogoči zagotavljanje potrebnih informacij o stanju in gibanjih na trgu dela v Sloveniji. Izkoristimo to možnost. Ne nazadnje, v Evropi se bo v letu 2011 izvajala raziskava o kompetencah odraslih, in sicer v okviru programa PIACC. To je nov program 
OECD, ki bo usmerjen v ključne usposobljenosti, potrebne za udeležbo v družbi znanja (štiri področja kompetenc - reševanje problemov, $\mathrm{v}$ tehnološkem okolju, bralnost, numeričnost). Rezultati raziskave v okviru programa PIACC bodo služili tudi kot orodje za ugotavljanje povezav med ključnimi kognitivnimi usposobljenostmi in gospodarsko uspešnostjo ter donosi od izobraževanja. Omenjena raziskava bi ob vključitvi Slovenije v program verjetno dala objektivno oceno o kompetentnosti slovenske delovne sile za spopadanje z izzivi prihodnosti.
1 COM (2003) 685 final. Izobraževanje in usposabljanje 2010.

2 Sklepi Sveta in predstavnikov vlad držav članic, ki so se sestali v okviru Sveta, o vlogi razvoja spretnosti in veščin pri spodbujanju ciljev lizbonske strategije, 2005/C 292/02.

3 COUNCIL DECISION on guidelines for the employment policies of the Member States, 10614/2/08, REV2, 7. julij 2008.

4 Council Resolution on the new skills for new jobs of 15. 11. 2007 (2007/C 290/01).

5 CEDEFOP je evropski center za razvoj poklicnega usposabljanja s sedežem v Solunu (Grčija).

6 Anticipating and Matching Labour Market Needs -

\section{Priloga št. 1: Obstoječi sistemi predvidevanja prihodnjih potreb}

\begin{tabular}{|l|l|l|}
\hline Sistem & Značilnosti sistema & Države članice \\
\hline Decentraliziran sistem & $\begin{array}{l}\text { Sistem je razvit večinoma na sektorski ali lokalni ravni. Sistematično predvidevanje } \\
\text { potreb po usposobljenosti ni izrazito izraženo. }\end{array}$ & $\begin{array}{l}\text { DK, ES, EL, HU, } \\
\text { LT, LV, PT, SK, SI }\end{array}$ \\
\hline Koordiniran necelovit sistem & Precej razvit sistem, ki vsebuje kvantitativno predvidevanje potreb po usposobljenosti. & CY, FI, IE \\
\hline mu celovitemu sistemu & $\begin{array}{l}\text { Sistem je sestavljen predvsem iz srednjeročnih kvantitativnih predvidevanj na ma- } \\
\text { kro ravni, ki vključuje nekatere kvalitativne elemente sektorskih predvidevanj. Ve- } \\
\text { liko ukrepov je usmerjenih v analizo na nacionalni, regionalni in sektorski ravni s } \\
\text { ciljem celostnega sistematičnega obravnavanja problematike. Večinoma se uvaja } \\
\text { redno spremljanje potreb po usposobljenosti. }\end{array}$ & CZ, EE, IT, PL \\
\hline Koordiniran celovit sistem & $\begin{array}{l}\text { Zelo razvit in preverjen sistem, ki sloni na srednjeročnih in kratkoročnih predvide- } \\
\text { vanjih na makro ravni, vključuje sistem sektorskih študij, redne raziskave /vprašal- } \\
\text { nike med delodajalci ter redne regionalne ankete o zaposlenosti. }\end{array}$ & $\begin{array}{l}\text { AT, DE, FR, NL, } \\
\text { SE, UK }\end{array}$ \\
\hline
\end{tabular}

\section{Prilogi št. 2 in 3: Prihodnje aktivnosti Evropske komisije glede predvidevanja prihodnjih potreb po usposobljenosti}

Evropska komisija naj bi že v tem letu vzpostavila t. i. evropsko opazovalnico trga dela. Komisija bo uvedla redno in sistematično ocenjevanje dolgoročne ponudbe in povpraševanja na trgih dela v EU do leta 2020 po sektorjih, poklicih, ravneh izobrazbe in državah. Posodobljene napovedi bodo objavljene vsaki dve leti od leta 2010 dalje skupaj s priložnostnimi opozorili o možnih neravnovesjih na trgu dela.

Nadalje bo pripravila analizo znanja in spretnosti ter potreb trga dela za ključne sektorje. Celoviti rezultati za 16 sektorjev, ki zajemajo 75 odstotkov vseh delovnih mest pri zasebnih delodajalcih v EU, bodo na voljo sredi leta 2009. V celoti bodo prikazali, kakšno je povpraševanje po delu in kakšne so posledice za prestrukturiranje. Z zainteresiranimi stranmi, zlasti obstoječimi sektorskimi odbori za socialni dialog, bo Komisija razpravljala o možnosti uvedbe »sektorskih svetov za zaposlovanje ter znanje in spretnosti« na ravni EU zaradi zbiranja podatkov, ki so na voljo v državah članicah in regijah, ter usmerjanja na podlagi znanja in izkušenj zainteresiranih strani ter sistemov izobraževanja in usposabljanja. 
A Jobs and Skills initiative, Doc 8411/08 SOC 213 EDUC 107 + COR 1, 8. 5. 2008.

7 Analiza, ki je bila predložena decembra 2008, vključuje EU-25, Norveško in Švico, ne vključuje pa novih držav članic Bolgarije in Romunije.

8 Nadomestna delovna mesta so tista delovna mesta, $k i$ se izpraznijo zaradi upokojitev ali umika delavcev s trga dela iz drugih vzrokov.

9 Neznana izobrazba vključuje 5.126 oseb (2006).

10 Institute for Prospective Technological Studies Report.

\section{LITERATURA}

Borjas, G. (2008). Labor economics, četrta izdaja. New York: McGraw-Hill/Irvin.

Cahuc, P., Zylberberg, A. (2004). Labor economics. Cambridge: MIT Press.

Cohen-Tanugi Laurent. Euroworld 2015: European Strategy for Globalisation, 2008. http://www.strategie. gouv.fr/article.php3?id_article=804, dne 10. 8. 2009.

Council Resolution of 27 June 2002 on lifelong learning (2002/C 163/01).

COM (2003) 685 final. Izobraževanje in usposabljanje 2010.

COM (2005) 548 - Recommendation of the European Parliament and of the Council on the key comptences on lifelong learning.

COM (2008) 868 - »Nova znanja in spretnosti za nova delovna mesta «. Napovedovanje in usklajevanje potreb trga dela ter znanj in spretnosti: 15.
Council decision on guidelines for the employment policies of the Member States (10614/2/08, REV2), 7. julij 2008.

Employment in Europe 2008.

Eurofound (2008d). More and better jobs: Patterns of employment expansion in Europe. European Foundation for the Improvement of Living and Working Conditions, European Monitoring Centre on Change.

ILO. Zelena delovna mesta.

Institute for Prospective Technological Studies (2002). Impact of technological and structural change on employment: prospective analysis 2020. Joint Research Centre, European Commission, Study for the Committee on Employment and Social Affairs of the European Parliament.

Institute for Prospective Technological Studies (2006). The Future of ICT and Learning in the Knowledge Society. EUR report 22218.

Future skill needs in Europe. Medium-term Forecast (Syntesis report). CEDEFOP. European Centre for the Development of Vocational Training. Luxembourg: Office for Official Publications of the European Communities, 2008: 121.

Future skill needs in Europe. Focus on 2020. CEDEFOP. European Centre for the Development of Vocational Training. Luxembourg: Office for Official $\mathrm{Pu}-$ blications of the European Communities, 2008: 25.

SEC (2008) 3058 - Commission Staff working document accompanying the New Skills for New Jobs. Anticipating and matching labour market and skills needs: 128. 